\title{
Table of statutory instruments
}

\begin{tabular}{|c|c|}
\hline Construction Contracts Exclusion Order & reg $18(8) \ldots \ldots$. \\
\hline 1998 (SI 1998/648).... & $\operatorname{reg} 18(18)(\mathrm{d})$ \\
\hline Management of Health and Safety at Work & $\operatorname{reg} 18(21)(b)$ \\
\hline Regulation 1999 (SI 1999/3242) & reg $18(26)$. \\
\hline reg $11 \ldots$ & reg $18(27)$ \\
\hline National Health Service (Functions of & g 47. \\
\hline Strategic Health Authorities and & $\operatorname{reg} 47 \mathrm{~K}$. \\
\hline Primary Care Trusts and & South London Heal \\
\hline stration Arrangements) & Service Trust (Appointment of Trust \\
\hline (England) Regulations 2002 (SI & Special Administrator) Order 2012, \\
\hline 2002/2375).. & SI 2012/1806 \\
\hline Public Contracts Regulations 2006 (SI & South London Healthcare National Health \\
\hline 2006/5) (PCR 2006) .....79, 171, 228 & Service Trust (Extension of Time for \\
\hline ..29, 107 & Trust Special Administrator to \\
\hline reg $18(5)$. & Provide a Draft Report) Order 2012 \\
\hline reg $18(6) \ldots$ & SI $2012 / 1824 \ldots$ \\
\hline
\end{tabular}


Yseult Marique - 9781781004555

Downloaded from PubFactory at 04/26/2023 04:57:30AM via free access 